\title{
Productivity and Profitability of Indian Mustard (Brassica juncea L.) Influenced by Drip Irrigation and Micronutrient Application Methods
}

\author{
Oma Shanker Bhukhar, A.C. Shivran, B.L. Dudwal, Priyanka Kumawat, Kuldeep \\ Singh, Rajesh Kumar Doutaniya and Suresh Kumar Kumawat \\ Sri Karan Narendera Agriculture University, Jobner-303 329, India \\ E-mail: omashankarbhukhar21@gmail.com
}

\begin{abstract}
A field experiment was conducted in split plot design with drip irrigation levels $(0.4,0.6$ and 0.8 IW/CPE ratios) in main plot and micronutrient application methods (control, soil, foliar and fertigation) in sub plot during Rabi season at S.K.N. College of Agriculture, Jobner (Rajasthan) during 2018. The scheduling of drip irrigation at 0.8 IW/CPE ratio recorded significantly higher plant height, dry matter accumulation, siliquae per plant, seeds per siliqua, test weight and seed yield over 0.4 IW/CPE ratios, which was statistically at par with 0.6 IW/CPE ratio. Drip irrigation at $0.8 \mathrm{IW} / \mathrm{CPE}$ ratio recorded higher monetary value. Among micronutrient application methods, fertigation significantly increased plant height at $80 \mathrm{DAS}$ and at harvest, dry matter accumulation at all growth stages, siliquae per plant and seeds per siliqua, seed yield over all other application method. Higher net return and B: C ratio also under fertigation.
\end{abstract}

Keywords: Mustard, IW/CPE, Drip irrigation fertigation

Oilseed crops are main source of energy in the diet of Indians. Though, India has become self-reliant with respect to food grains but still lagging behind in the production of oilseeds. India is a key player in the global oilseeds scenario with 12-15 per cent of oilseeds area, 6-7 per cent of vegetable oils production, 9-11 per cent of the total edible oils consumption and 14 per cent of vegetable oil imports. Despite of being the largest cultivator of oilseeds at the global level, our country, who was an exporter of oil till fifties, has now become a major importer of edible oil which involves foreign exchange and thus increase the burden to government exchequer. Nutrient management and irrigation are the most important agronomic factors that affect the yield of Indian mustard (Brassica juncea L.). Drip irrigation is one of the most efficient methods of irrigation. It is viewed as a promising technology for its ability to support farmers in raising incomes and reducing poverty (IWMI Water Policy Briefing 2006). A number of benefits have been ascribed to the use of drip irrigation. In addition to saving of water these include increased yield and productivity of crops, labour cost savings, electricity savings, lesser pumping hours and hence easier irrigation, better crop growth and also better soil health. In IW/CPE approach, known amount of irrigation water is applied when cumulative pan evaporation reaches predetermined level. Multiple micronutrient deficiencies are emerging at a faster rate in intensively cultivated high production areas due to greater removal of soil micronutrients through annual biomass harvest. Data of 1.48 lakh surface soil samples revealed $45,33,8.3,4.5$ and 3.3 per cent deficiency of $\mathrm{Zn}, \mathrm{B}, \mathrm{Fe}, \mathrm{Mn}$ and $\mathrm{Cu}$, respectively (Singh, 2019). More or less similar trend in deficiencies of micronutrients in Maharashtra soils as that of Indian soils were noticed by Malewar and Syed (2016). The deficiency range of micronutrients especially $\mathrm{Zn}$ and $\mathrm{B}$ in oilseed growing soils emphasizes the need to focus immediate attention on balanced nutrient management practices. The production of mustard in the region, state and in country often suffers from a higher degree of variation in the annual production owing to their predominant cultivation under low and uncertain rainfall situations and further handicapped by input starved conditions with poor crop management. There is limited scope for expansion of area under mustard and also the irrigation. Increasing the vertical growth in productivity is the feasible option. Again, vertical growth by increasing the crop productivity demands higher inputs, which are costly and limited. Therefore, what is really needed is the increased input use efficiency.

Fertigation is a modern agro technique, combining water and fertilizer application through irrigation provides an excellent opportunity to both maximize yield and minimize environmental pollution. Fertigation is considered an integral part of plant nutrient management and generate a concentrated and space limited root system within the wetted soil volume. It localizes the water supply and this triggers the development of a restricted root system that requires frequent replenishment of the nutrients. Applying nutrients in 
the irrigation water may satisfy this requirement. In a fertigation system, the timing, amounts, concentrations and ratios of the nutrients are easily controlled. Due to this improved control, crop yields are greater than those produced by a simple fertilizer application and irrigation system. Such yield increases should not be attributed to fertigation only because the changes in the agro-technique are accompanied by other improvements in crop management. In drip irrigation, the wetted soil volume and thus the active root zone is reduced under drippers and this small volume does not allow the addition of all plant nutrients needed by the plants. Rather, fertiliser needed is to be applied frequently and periodically in small amount with the each irrigation to ensure adequate supply of water and nutrient in the root zone. Therefore, as a result of the shift from surface irrigation to drip method of irrigation, fertigation becomes the most common fertilisation in the irrigated agriculture. The use of soluble and compatible fertilisers, good quality irrigation water and application of actual crop water need are the prerequisite of the successful fertigation system.

\section{MATERIAL AND METHODS}

The experiment was conducted at S.K.N. College of Agriculture, Jobner. The region fall under Agroclimatic Zone Illa of Rajasthan (Semi-arid Eastern Plains). The experimental soil was loamy sand in texture, alkaline in reaction (8.1), poor in organic matter (0.18), low in available nitrogen $\left(129.50 \mathrm{~kg} \mathrm{ha}^{-1}\right)$, medium in phosphorus $(17.10 \mathrm{~kg}$ $\mathrm{ha}^{-1}$ ) and potassium content (181.20 kg ha ${ }^{-1}$ ). Field capacity and PWP of soil was 10.85 and 4.32 per cent, respectively. The experiment consisting of 12 treatment combinations with three levels of drip irrigation in main plot (drip at 0.4, 0.6 and 0.8 IW/CPE ratio) and four levels of micronutrient application method in sub plot (control, soil application, foliar application and fertigation). The experiment was conducted in split plot design and replicated four times. The seeds of mustard variety Laxmi @ 5 kg ha ${ }^{-1}$ was used for sowing in the experiment. Mustard seeds were sown at a spacing of $30 \times 10$ $\mathrm{cm}^{2}$ apart. The experimental mustard crop was fertilized uniformly with $60: 40 \mathrm{~kg} / \mathrm{ha}$ of $\mathrm{N}$ and $\mathrm{P}$ respectively. Half of the nitrogen along with full amount of phosphorous was applied at the time of sowing as basal. Five plants for each treatment were taken for recording the various data. Data on yield attributes and yield were recorded as per standard process at harvest. Various indices were used to assess the effectiveness of water management practices viz., Consumptive use of water by Dastane (1972) and Wateruse-efficiency by Viets (1961). The economics of treatments was computed on the basis of prevailing market price of input and outputs for each treatment. Net returns and B: C ratio was calculated by following formulas.

Net returns $\left(\mathrm{Rs} \mathrm{ha}^{-1}\right)=$ Gross returns $\left(\mathrm{Rs} \mathrm{ha}^{-1}\right)-$ Total cost of cultivation (C3) (Rs ha-1)

$$
B: C \text { ratio }=\frac{\text { Net return }(\mathrm{Rs} / \mathrm{ha})}{\text { Cost of cultivation }(\mathrm{Rs} / \mathrm{ha})}
$$

\section{RESULTS AND DISCUSSION}

\section{Effects of Drip Irrigation}

Growth parameters: Scheduling of drip irrigation at 0.8 IW/CPE ratios, recorded significantly higher plant height (150.49 and $196.00 \mathrm{~cm}$ ) as compared to $0.4 \mathrm{IW} / \mathrm{CPE}$ ratios at 80 DAS and at harvest, which remained statistically at par with 0.6 IW/CPE ratios (Table 1). The drip irrigation level at

Table 1. Effect of drip irrigation level and micronutrient application method on plant height and dry matter accumulation of mustard

\begin{tabular}{|c|c|c|c|c|c|c|}
\hline \multirow[t]{2}{*}{ Treatment } & \multicolumn{3}{|c|}{ Plant height $(\mathrm{cm})$} & \multicolumn{3}{|c|}{ Dry matter accumulation per meter row length $(\mathrm{g})$} \\
\hline & 40 DAS & 80 DAS & Harvest & 40 DAS & 80 DAS & Harvest \\
\hline \multicolumn{7}{|l|}{ Drip irrigation level } \\
\hline $0.4 \mathrm{IW} / \mathrm{CPE}$ & 70.90 & 129.29 & 177.30 & 34.54 & 100.95 & 155.16 \\
\hline $0.6 \mathrm{IW} / \mathrm{CPE}$ & 71.99 & 143.59 & 193.70 & 38.98 & 110.60 & 175.39 \\
\hline $0.8 \mathrm{IW} / \mathrm{CPE}$ & 72.49 & 150.49 & 196.00 & 40.65 & 114.99 & 185.13 \\
\hline$C D(P=0.05)$ & NS & 10.99 & 14.72 & 2.95 & 8.44 & 13.37 \\
\hline \multicolumn{7}{|c|}{ Micronutrient application method } \\
\hline Control & 66.30 & 123.55 & 173.30 & 32.20 & 97.39 & 154.70 \\
\hline Soil application & 70.80 & 137.15 & 185.90 & 37.08 & 105.96 & 168.45 \\
\hline Foliar application & 74.60 & 147.55 & 197.30 & 40.90 & 113.76 & 178.95 \\
\hline Fertigation & 75.48 & 156.25 & 199.50 & 42.05 & 118.27 & 185.46 \\
\hline $\mathrm{CD}(\mathrm{P}=0.05)$ & 3.91 & 7.91 & 10.52 & 2.14 & 6.07 & 9.67 \\
\hline
\end{tabular}


$0.8 \mathrm{IW} / \mathrm{CPE}$ ratio, recorded significantly maximum dry matter accumulation $(40.65,114.99$ and $196.00 \mathrm{~g}$ ) as compared to 0.4 IW/CPE ratio at 40, 80 DAS and at harvest, while it remained statistically at par with $0.6 \mathrm{IW} / \mathrm{CPE}$ ratio (). The crop plants are able to maintain higher water potential with increasing IW/CPE ratio under drip irrigation which improves physiological and biochemical activities. This leads to improved growth of plant. Beside it, reduced water supply causes closure of stomata which raises the plant temperatures consequently increases respiration leading to higher break down of assimilates and ultimately poor growth and reduced dry matter accumulation. Similar results have also been reported by Bhunia et al (2004) and Choudhary et al (2005).

Yield attributes and yield: The drip irrigation level at 0.8 IW/CPE ratio recorded highest no. of siliqua plant ${ }^{-1}$ (288.80), no. of seed siliqua ${ }^{-1}(15.64)$, test weight (3.86 g), seed (18.06 $\mathrm{q} \mathrm{ha}^{-1}$ ), straw (69.66 q ha ${ }^{-1}$ ) and biological yield (88.26 q ha-1) remain at par on 0.6 IW/CPE ratio over $0.4 \mathrm{IW} / \mathrm{CPE}$ ratio (Table 2). This increase in seed yield might be due to maintenance of sufficient moisture in root zone during critical stages of the crop growth, resulting in higher yields. Higher seed yield with increasing IW/CPE ratio could be the resultant of cumulative beneficial effects of irrigation schedules first on vegetative growth and later on better partitioning of photosynthates towards the sink. These findings are in close conformity with those of Solanki et al. (2014) and Kunapara et al (2017).

Economics: The higher net returns and $\mathrm{B}$ : $\mathrm{C}$ ratio of (Rs. $42639 \mathrm{ha}^{-1}$ and 1.87 , respectively) at $0.8 \mathrm{IW} / \mathrm{CPE}$ ratio were significantly higher over $0.4 \mathrm{IW} / \mathrm{CPE}$ ratio (and remained statistical at par with 0.6 IW/CPE ratio (Table 3 ). The significantly higher net returns obtained under 0.8 IW/CPE ratio was due to higher seed and straw yields along with higher price of mustard. The total cost of production increased slightly with an increase in IW/CPE ratio for scheduling irrigation, because the irrigation charges were insignificant as compared with other expenses. The cost involved under this treatment was comparatively lower than its additional income, which led to more returns under this treatment. These findings are in accordance with the results reported by Mahalakshmi et al (2011) and Rajiv (2012).

\section{Effects of Micronutrient Application Method}

Growth: Among application method, fertigation recorded significantly higher plant height at 40,80 DAS and at harvest (75.48, 156.25 and $199.50 \mathrm{~cm}$, respectively) however, it remained at par with foliar application method (Table 1). The fertigation recorded maximum dry matter accumulation at 40 , 80 DAS and harvest $(42.05,118.27$ and $185.46 \mathrm{~g}$, respectively) it remained at par with foliar application method as compared to control and soil application. Among the methods of nutrient application, foliar application is

Table 3. Effect of drip irrigation level and micronutrient \begin{tabular}{ccc}
\multicolumn{3}{c}{ application method on protein and oil content (\%) } \\
\hline Treatment & Protein content (\%) & Oil content (\%)
\end{tabular}

\section{Drip irrigation level}

$\begin{array}{lcc}0.4 \mathrm{IW} / \mathrm{CPE} & 20.45 & 38.74 \\ 0.6 \mathrm{IW} / \mathrm{CPE} & 21.95 & 39.24 \\ 0.8 \mathrm{IW} / \mathrm{CPE} & 22.57 & 38.94 \\ \mathrm{CD}(\mathrm{P}=0.05) & \mathrm{NS} & \mathrm{NS}\end{array}$

Micronutrient application method

$\begin{array}{lll}\text { Control } & 18.50 & 38.42\end{array}$

Soil application $\quad 20.94 \quad 38.35$

Foliar application $\quad 22.88 \quad 39.30$

Fertigation $\quad 24.31 \quad 39.83$

$\mathrm{CD}(\mathrm{P}=0.05) \quad 2250 \quad \mathrm{NS}$

Table 2. Effect of drip irrigation level and micronutrient application method on yield attributes and yield of mustard

\begin{tabular}{|c|c|c|c|c|c|c|}
\hline Treatment & $\begin{array}{l}\text { No. of siliquae } \\
\text { plant }^{-1}\end{array}$ & $\begin{array}{l}\text { No. of seed } \\
\text { siliqua }^{-1}\end{array}$ & $\begin{array}{l}\text { Test weight } \\
\text { (g) }\end{array}$ & $\begin{array}{c}\text { Seed yield } \\
\left(q \text { ha }^{-1}\right)\end{array}$ & $\begin{array}{c}\text { Straw yield } \\
\left(q \text { ha }^{-1}\right)\end{array}$ & $\begin{array}{c}\text { Biological yield } \\
\left(\mathrm{q} \mathrm{ha} \mathrm{a}^{-1}\right)\end{array}$ \\
\hline \multicolumn{7}{|l|}{ Drip irrigation level } \\
\hline 0.4 IW/CPE & 257.90 & 13.32 & 3.20 & 15.78 & 57.63 & 73.41 \\
\hline 0.6 IW/CPE & 281.90 & 14.95 & 3.66 & 18.06 & 66.31 & 84.37 \\
\hline $0.8 \mathrm{IW} / \mathrm{CPE}$ & 288.80 & 15.64 & 3.86 & 18.60 & 69.66 & 88.26 \\
\hline$C D(P=0.05)$ & 21.56 & 1.14 & 0.28 & 1.38 & 4.17 & 5.30 \\
\hline \multicolumn{7}{|c|}{ Micronutrient application method } \\
\hline Control & 240.50 & 12.27 & 3.13 & 14.17 & 56.39 & 70.56 \\
\hline Soil application & 267.90 & 14.45 & 3.46 & 17.37 & 62.90 & 80.27 \\
\hline Foliar application & 289.80 & 15.5 & 3.74 & 18.65 & 68.18 & 86.83 \\
\hline Fertigation & 306.60 & 16.34 & 3.97 & 19.73 & 70.66 & 90.39 \\
\hline $\mathrm{CD}(\mathrm{P}=0.05)$ & 15.42 & 0.83 & 0.20 & 1.00 & 3.65 & 4.65 \\
\hline
\end{tabular}


Table 4. Effect of drip irrigation level and micronutrient application method on net returns, B: C ratio, consumptive use of water and water use efficiency in mustard

\begin{tabular}{|c|c|c|c|c|}
\hline Treatment & Net return $\left(\mathrm{Rs} \mathrm{ha}^{-1}\right)$ & $\mathrm{B}: \mathrm{C}$ ratio & $\begin{array}{c}\text { Consumptive use of } \\
\text { water }(\mathrm{mm})\end{array}$ & $\begin{array}{l}\text { Water use efficiency } \\
\left(\mathrm{kg} \mathrm{ha} \mathrm{C}^{-1}-\mathrm{mm}\right)\end{array}$ \\
\hline \multicolumn{5}{|l|}{ Drip irrigation level } \\
\hline $0.4 \mathrm{IW} / \mathrm{CPE}$ & 30413 & 1.65 & 191.1 & 8.26 \\
\hline 0.6 IW/CPE & 40784 & 1.85 & 264.3 & 6.83 \\
\hline $0.8 \mathrm{IW} / \mathrm{CPE}$ & 42639 & 1.87 & 334.6 & 5.56 \\
\hline$C D(P=0.05)$ & 2555 & 0.12 & 20.06 & 0.53 \\
\hline \multicolumn{5}{|c|}{ Micronutrient application method } \\
\hline Control & 30382 & 1.77 & 263.33 & 5.58 \\
\hline Soil application & 34271 & 1.67 & 263.33 & 6.84 \\
\hline Foliar application & 41215 & 1.82 & 263.33 & 7.34 \\
\hline Fertigation & 45914 & 1.9 & 263.33 & 7.77 \\
\hline$C D(P=0.05)$ & 2250 & 0.10 & 15.57 & 0.35 \\
\hline
\end{tabular}

recognized as an important method of fertilization, since foliar spray usually penetrate the leaf cuticle or stomata and enters the cells facilitating easy and rapid utilization of nutrients. This leads to efficient utilization of micronutrients. The observed improvement in overall vegetative growth of the crop with the application method of micronutrient in the present investigation is in conformity with those of Sintupachee et al (2010) and Moosavi and Ronaghi (2011).

Yield attributes and yield: Micronutrient application method of fertigation recorded significant improvement in yield attributes and yield of mustard (Table 2). The fertigation recorded highest no. of siliqua/plant, no. of seed/siliqua and test weight $(\mathrm{g}$ ) followed by foliar application over control. Same trend follow in yield i.e. fertigation recorded highest seed, straw and biological yield (q ha $\left.{ }^{-1}\right)(19.73,70.66$ and 90.39, respectively) followed by foliar application. The combined application of micronutrients provided fertigation greater availability of nutrients for the development of reproductive structures and increase in the number of grains and grain weight. Since boron and combination of all micronutrients were responsible for the translocation of food materials in plants therefore it played a vital role in grain setting as well as higher number of grain. These results are in close conformity with the findings of Singh and Choudhari (2001).

Oil and protein content (\%): The micronutrient application by all methods significantly increased the oil and protein content in mustard seed (Table 3). that fertigation (39.83 and $22.88 \%$ ), was at par with foliar application (39.30 and 22.88 $\%)$ and recorded significantly highest protein content in mustard seed over control and soil application Higher nitrogen in seed is directly responsible for higher protein because it is a primary component of amino acids which constitute the basis of protein. These results are in close conformity with the findings of Mona et al (2015).
Economics: Significantly higher net returns (Rs. 45914 ha $^{-1}$ ) and $B$ : $C$ ratio (1.90) was under fertigation over control, soil and foliar application (Table 4). The highest income obtained in fertigation due higher yield. Similar findings were also observed by Jabran et al (2011) and Shankar et al (2017).

\section{Water use Parameters}

Consumptive use of water: The higher consumptive use of water obtained in $0.8 \mathrm{IW} / \mathrm{CPE}$ ratio as compared to 0.4 IW/CPE ratios. The $0.6 \mathrm{IW} / \mathrm{CPE}$ ratios were statistically at par with $0.8 \mathrm{IW} / \mathrm{CPE}$ ratios. Water application with $0.8 \mathrm{IW} / \mathrm{CPE}$ provide higher water to crop, which leads to more water availability and consumptive use by crop.

Water use efficiency (kg ha-1- $\mathbf{m m})$ : The higher water use efficiency was recorded in $0.4 \mathrm{IW} / \mathrm{CPE}$ ratio $\left(8.26 \mathrm{~kg} \mathrm{ha}^{-1}-\right.$ $\mathrm{mm}$ ) followed by $0.6 \mathrm{IW} / \mathrm{CPE}$ ratio $\left(6.83 \mathrm{~kg} \mathrm{ha}^{-1}-\mathrm{mm}\right)$. Among different micronutrient application method, fertigation recorded higher water use efficiency $(7.77 \mathrm{~kg} \mathrm{ha-1}-\mathrm{mm})$ statistically at par on foliar application $\left(7.34 \mathrm{~kg} \mathrm{ha}^{-1}-\mathrm{mm}\right)$.

\section{CONCLUSION}

Productivity and profitability of mustard is significantly influenced by different drip irrigation levels and micronutrients application methods. Maximum growth, quality and seed yield was obtained with drip irrigation at 0.6 IW/CPE in conjunctions with micronutrient application method as fertigation.

\section{REFERENCES}

Bhunia SR, Chauhan RPS and Yadav BS 2005. Effect of nitrogen and irrigation on water use, moisture extraction pattern, nutrient uptake and yield of fennel (Foeniculum vulgare). Indian Journal of Agronomy 50(1): 73-76.

Choudhary VK 2005. Effect of planting methods and drip irrigation levels on growth, yield and quality of baby corn. M.Sc. (Agri.) Thesis, UAS, Bangalore. 
Dastane NG 1972. A practical manual for water use research in agriculture. Nav Bharat Prakashan Poona, India.

DRMR 2014. Fertigation in Indian mustard. Directorate of rapeseedmustard research (ICAR) Sewar, Bharatpur, p. 1-36.

Jabran, K, Cheema ZA, Farooq M and Muhammad BK 2011. Fertigation and foliar application of fertilizers alone and in combination with canola extracts enhances yield in wheat. Crop and Environment 2(1): 42-45.

Kunapara AN, Subhaiah R, Prajapati GV and Makwana JJ 2016. Influence of drip irrigation regimes and lateral spacing on cumin productivity. Current world Environment 11(1): 333-337.

Mahalakshmi KL, Avil Kumar K, Reddy MD and Uma DM 2011. Response of rabi pigeonpea (Cajans cajan L.) to different levels of drip irrigation. Journal of Research 39(4): 101-103.

Malewar GU and Syed Ismail 2016. Increasing significance of micronutrient in sugarcane production. Special paper presented at $X V^{\text {th }}$ cane development workshop on soil fertility management, Vasantdada Sugar Institute. Manjari (Pune) Sept. 17-18, 24-32.

Moosavi AA and Ronaghi A 2011. Influence of foliar and soil applications of iron and manganese on soybean dry matter yield and iron-manganese relationship in calcareous soil. Australian Journal of Crop Science 5(12): 1550-1556.

Rajiv S 2012. Scheduling of irrigation for hybrid maize under drip irrigation. M.Sc (Agric.) Thesis, UAS, Bangalore.

Shankar MA, Thimmegowda MN, Bhavitha NC and Manjunatha BN 2017. Comparative efficiency of soil and foliar application of boron on growth and yield of finger millet (Eleusine coracana L.). Mysore Journal of Agriculture Sciences 51(2): 430-435.

Singh AL and Chaudhari V 2019. Drip irrigation: A potential system for micronutrient application in groundnut in semi-arid region. National Research Center for Groundnut, Junagadh pp 501-507.

Sintupachee K, Chareonsook J and Thongpae S 2010. Effect of some iron sources on yields of groundnut in calcareous soil, lop buri series, proceedings of the 48th kasetsart university annual conference, kasetsart pp. 3-5.

Solanki RM, Sagarka BK, Dabhi BM, Shaikh MA and Gohil BS 2014. Response of chickpea to drip irrigation and integrated nutrient management under Saurashtra Region of Gujarat. Agriculture: Towards a New Paradigm of Sustainability. ISBN: 978-986.

Viets FC 1961. Fertilization and efficient use of water. Advances in Agronomy 14 : 223-264.

Received 06 October, 2021; Accepted 10 January, 2022 